\title{
AKTYVUSIS IR PASYVUSIS GRAMATIKOS MINIMUMAS MOKANT UŽSIENIO KALBOS
}

\author{
Aleksandras Velička \\ Vilniaus Gedimino technikos universitetas, Saulètekio al. 11, LT-10223 Vilnius \\ El. paštas: vvka@vv.vtu.lt
}

\begin{abstract}
Gramatikos mokymas nekalbinèje aukštojoje mokykloje turi ir praktinę, ir lavinamaja reikšmę. Praktiniai uždaviniai yra svarbiausi. Praktine gramatikos mokymosi svarbą lemia tai, kad désningumu apibendrinamasis pobüdis palengvina kalbos mokymasi. Šiame straipsnyje norima išaiškinti gramatikos reikšmę ir jos paskirtị receptyviosioms, taip pat ir reproduktyviosioms kalbinès veiklos rūšims mokyti. Metodikos tyrimai parodè, kad receptyviuju ir reproduktyviujų kalbinès veiklos rūšiu gramatikos dalykai tam tikra prasme skiriasi. Todèl reikia skirti pasyvųji ir aktyvuji gramatikos minimumą. Aktyvusis gramatikos minimumas turi atitikti pagrindines bendrinès šnekamosios kalbos normas. Bütu galima išskirti du gramatinio minimumo pogrupius: 1) gramatikos dalykai, būdingi techniniam mokslo stiliui; 2) dalykai, paplitę bendrineje šnekamojoje kalboje. Darbe aptariami ir pasyviojo, ir aktyviojo minimumo klausimai, pateikiami abu minimumai.
\end{abstract}

Reikšminiai žodžiai: gramatikos minimumas, atrankos kriterijai, statistinė apskaita, receptyviosios ir reproduktyviosios kalbinès veiklos rūšys, būdingos gramatinès struktūros ir modeliai, lingvistinè statistika.

\section{Ivadas}

Bendrinė gramatika konkrečioje kalboje apibūdina ir determinuoja jos struktūrą. Nagrinejjant gramatiką kalbos mokymo požiūriu, ji detalizuojama, išskiriami tam tikri gramatikos dalykai, remiantis dažniausiai dviem kriterijais:

1) tam tikro gramatikos dalyko dažnumas ir vartojimas šnekamojoje arba rašytinèje kalboje;

2) skyrimas jo aktyviajai ar pasyviajai gramatikai.

Bendrinès gramatikos detalizavimo būtinumas mokant užsienio kalbos šiuo metu yra neginčytinas dalykas. Deja, mokslinio tokio gramatikos dalijimo pagrindimo dar neturime.

Daugelyje darbų, nagrinèjančių užsienio kalbos gramatikos mokymą ịvairaus profilio aukštosiose mokyklose, bandyta, išskiriant tam tikrus gramatikos objektus, remtis pirmuoju, t. y. nagrinejjamos kalbos gramatikos reiškinio dažnumu
(Benes 1986: 80; Hoffmann 1988: 270). Šiuo atveju mokomųjų dalykų atranka susiejama su jų prezentacijos problema.

Buvo stengiamasi detalizuoti gramatikos dalykus pasitelkiant gerokai geresnius ir rekomenduotinus kriterijus. Remiantis šiais kriterijais, kalbos sistemoje išskiriami jos posistemiai, t. y. mikrosistemos. Tai ypač aktualu mokantis kalbos, nes padeda neutralizuoti interferenciją tarp sąveikaujančių kalbų.

Kiti autoriai, detalizuodami kalbos sistemą, itin svarbiu dalyku laiko dviejų gramatikos tipų sukūrimą: t. y. aktyviosios ir pasyviosios (Берман 1978; Щерба 1974: 112-131). Išsami pateiktų kalbos sistemos detalizacijos variantų analizè gali būti atlikta tik didelès apimties darbe. Mes tenkinomès tik pagrindiniais racionalios gramatikos dalykų atrankos mokomiesiems tekstams klausimais. Parašyta daug darbų, ku- 
riuose nagrinëjami gramatinès medžiagos atrankos kiekybiniai rodikliai. Jais remiantis, autorių nuomone, atrinkta gramatikos medžiaga leistų realizuoti tokias kalbinès veiklos rūšis kaip skaitymą ir kalbejjimą. Šiuo atveju dažnumo, aktyvumo ir pasyvumo kriterijai tapatinami.

Šių darbų autoriai mano, kad duomenys, gauti analizuojant teksto gramatinių dalykų dažnumo kriterijus, yra lemiami atrenkant gramatikos dalykus, kurie turètų būti įtraukti ị mokomąji minimumą, kita dalis - atmestina. Neneigdami kiekybinių atrankos kriterijų svarbos atrenkant gramatikos mokomuosius dalykus, bandysime, remdamiesi kalbos tyrinejjimais, parodyti, kokia neigiama ịtaka gali būti mokomajam darbui, jeigu kiekybinị kriteriju gramatikos atrinkimo darbe laikysime vieninteliu dalyku.

Noretume pasiremti V. Ostrouchovos (Остроухова 1980: 123) darbu, kuriame ji pateikia gramatikos minimumą specialybès literatūrai skaityti vokiečių kalba:

- Paprasti vientisiniai sakiniai.

- Prijungiamieji sakiniai.

- Präsens, Imperfekt, Futurum Aktiv.

- Präsens, Imperfekt Passiv.

- Präsens, Passiv des Zustandes.

- Modalverben mit Infinitiv und Infinitiv Passiv.

- Išplèstinis pažyminys.

- Partizip I mit zu.

- Dalyvių grupès.

- Bendraties grupés.

- Bendraties grupė $u m \ldots z u$.

- Haben, sein + zu + Infinitiv.

- Sich lassen + Infinitiv.

Autorius mano, kad iš modalinių veiksmažodžių užtenka paimti tik können, müssen, sollen.

Deja, siūlomos autorès rekomendacijos atrinkti gramatikos dalykus skaitymo tikslams gerokai skiriasi nuo to, ką siūlo kiti mokomụjų priemonių mokslinei-techninei literatūrai skaityti ir versti autoriai. Šiose mokymo priemonèse taip pat vyrauja tokie gramatikos dalykai kaip konjunktyvas, parodomieji įvardžiai, nuolaidos šalutiniai sakiniai, veiksmažodžiai scheinen, brauchen su bendratimi ir kiti dalykai.
Galima būtų daryti išvadą, kad empirinès srities atstovai savo stebejjimuose ir išvadose daro klaidų ir kad straipsnio autorè yra teisi pateikdama savo duomenis. Tačiau mūsų tyrimas iš dalies paneigè straipsnio autorès prielaidas, kad dažnumo kriterijus yra vienintelis ir lemiamas atrenkant gramatikos dalykus mokomiesiems tikslams.

\section{Tiriamojo darbo analizè}

2003 m. rudens semestre VGTU Verslo vadybos fakultete trečio kurso studentams buvo pateikti versti specialybės tekstai. Eksperimente dalyvavo 75 studentai, kuriems buvo pateikta 150 tekstų. Vidutinè teksto apimtis 850-900 spaudos ženklų. $2004 \mathrm{~m}$. pavasario semestre įstaigu vadybos antrojo kurso studentams buvo pateikta versti 100 tekstų. Studentų skaičius - 56 . Teksto apimtis - ta pati. Eksperimento tikslas buvo patikrinti studentų žinias, mokejjimus ir igūdžius verčiant specialybès tekstus pasirengiant baigiamajam egzaminui. Svarbiausia buvo nustatyti, kokie gramatikos dalykai studentams verčiant tekstus yra sunkiausi. Studentų darbų analizè parodè tokius rezultatus. Jie pateikiami lentelèje.

Lentelès skaičiai rodo, kad mūsų rodikliai iš dalies nesutampa su V. Ostrouchovos duomenimis. Paprastas vientisinis sakinys (jis yra autorès gramatinio minimumo sąraše, kuris buvo sudarytas pagal dažnumo kriterijų, teikia skaitant $5 \%$ klaidų, o neittraukti ị minimumą parodomieji įvardžiai anaforinejje funkcijoje ir konjunktyvas verčiant specialybès tekstą sudaro $63 \%$ ir $52 \%$ klaidų.

Iš to galima daryti išvadą, kad dažnumo kriterijaus neužtenka atrenkant gramatikos minimumą mokomiesiems tikslams. Jis turètų būti papildytas kitais, adekvatesniais, kriterijais. Matyt, bendrasis ieškomasis, kriterijus turètų būti paties gramatikos reiškinio reikšmè minimaliame kontekste, t. y. sakinyje. Tačiau, laikantis šio požiūrio, ì gramatikos minimumą turi būti ịtraukti beveik visi dalykai, nes ne- 
Studentu darbu analizés rezultatai

\begin{tabular}{|c|c|c|c|c|}
\hline $\begin{array}{l}\text { Eil. } \\
N r .\end{array}$ & Gramatine tema & $\begin{array}{l}\text { Bendrasis gramatikos } \\
\text { dalyko skaičius tekstuose }\end{array}$ & $\begin{array}{l}\text { Klaidur } \\
\text { skaičius }\end{array}$ & $\begin{array}{c}\text { Klaidos } \\
\text { procentais }\end{array}$ \\
\hline 1 & $\begin{array}{l}\text { Parodomieji ịvardžiai nominatyvinèje } \\
\text { funkcijoje }\end{array}$ & 99 & 63 & 63 \\
\hline 2 & Konjunktyvas & 128 & 67 & 52 \\
\hline 3 & Atžvilgio kilmininkas & 41 & 21 & 51 \\
\hline 4 & $\begin{array}{l}\text { Būdvardžių ir prieveiksmių aukščiausiasis } \\
\text { laipsnis }\end{array}$ & 99 & 41 & 40 \\
\hline 5 & $\begin{array}{l}\text { Būdvardžių ir prieveiksmių aukštesnysis } \\
\text { laipsnis }\end{array}$ & 284 & 121 & 38 \\
\hline 6 & $\begin{array}{l}\text { Konstrukcijos haben, sein }+ \text { Inf. } \\
\text { Beasmenis pasyvas }\end{array}$ & 113 & 44 & 37 \\
\hline 7 & Išplèstinis pažyminys & 50 & 17 & 34 \\
\hline 8 & Išskirtinès dalyvio grupès & 480 & 163 & 35 \\
\hline 9 & Veiksmažodžių valdymas & 64 & 18 & 28 \\
\hline 10 & Konstrukcija sein + Partizip II galininkinio & 559 & 152 & 27 \\
\hline 11 & $\begin{array}{l}\text { veiksmažodžio } \\
\text { Konstrukcija } z u+\text { Partizip I }\end{array}$ & 175 & 46 & 26 \\
\hline 12 & Veiksmažodis es ir jo vartojimas & 43 & 10 & 23 \\
\hline 13 & $\begin{array}{l}\text { Konstrukcija sich lassen + Infinitiv } \\
\text { Bendraties grupés }\end{array}$ & 228 & 40 & 17 \\
\hline 14 & Pažymio šalutiniai sakiniai & 74 & 13 & 17,5 \\
\hline 15 & Prijungiamieji sakiniai (išskyrus pažyminio) & 220 & 32 & 14 \\
\hline 16 & Passiv & 556 & 77 & 13,8 \\
\hline
\end{tabular}

relevantiškujų požymių šiuo atveju yra nedaug ir gramatikos dalykai, kuriuos jie apibūdina, yra paradigmų sudedamosios dalys ir jų eliminuoti iš visumos negalima. Tokiu atveju atrodytų, kad gramatinis minimumas sutampa su maksimumu. Išvada peršasi paradoksali. Tačiau dalykas yra tas, kad ir pats klausimas dèl gramatinio minimumo ir maksimumo, skirtų „receptyviajam“ išmokimui, yra ne visai korektiškas. Norint visiškai suvokti gaunamą informaciją, būtina mokèti gramatikos dalykų visumą. Todèl galima kelti klausimą dèl kiekvieno gramatinio dalyko "lyginamojo svorio“, kuris determinuojamas daugeliu veiksnių, kuriuos norètume trumpai aptarti.

1. Jeigu studijuojamosios kalbos ir gimtosios kalbos formos arba konstrukcijos sutampa, tuomet jų „lyginamasis svoris“ mažèja. Pvz., esantys V. Ostrouchovos sąraše paprasti vientisiniai sakiniai savo struktūra paprastai sutampa su gimtosios kalbos sakiniais, todèl nereikia specialaus mokymo.
2. Kurios nors užsienio kalbos gramatikos formos reikšmès visiškas identifikavimas, remiantis gimtosios kalbos forma, mažina jos „lyginamąji svorị‘. Pvz., visos vokiečių kalbos pasyvo formos yra verstinès iš Präsens laiko, todèl pastarajam išmokti reikia intensyvaus mokymosi.

3. Tai, kad užsienio ir gimtojoje kalboje yra panašių arba anoniminių gramatinių formų, didina jų „lyginamąjị svorị“, nors šios gramatinès formos rečiau pasitaiko tekstuose. Pvz., konjunktyvo formos, neturinčios tik joms būdingų požymių, būna rimta prielaida atsirasti interferencijai, todèl jų reikia intensyviai mokytis.

4. Diskretinès nevienalytès gramatinès konstrukcijos taip pat turi didesnị „lyginamaji svorị". Pvz., būtinumo, privalumo reikšmè konstrukcijose sein $+z u+$ Infinitiv arba haben $+z u+$ Infinitiv, išreiškiama pavieniais tam tikra tvarka išdèstytais elementais, reikalauja gerokai daugiau pastangų jas išmokti. Tai parodè tyrimai. Mūsų pateiktoje lenteleje konstrukcijoms haben, sein + $z u+$ Infinitiv tenka $37 \%$ klaidu, visoms bendra- 
ties konstrukcijoms, kurių pagrindinè reikšmè reiškiama kompaktiška grupe ir dar vienu elementu - um, statt, ohne, tenka tik $10 \%$ klaidų.

5. Kai gimtojoje kalboje nèra užsienio kalbos dalyko, yra didesnio jo „lyginamojo svorio“ priežastis, pvz., veiksmažodžio reikšmė sąlygos šalutiniame sakinyje be jungtuko.

6. Mokomojo dalyko formos informatyvumas yra labai svarbus jo lyginamojo svorio veiksnys.

7. Pvz., vokiečių kalbos būdvardžių ar prieveiksmių galūnès daugeliu atvejų yra raktas atpažinti išplèstinę pažyminị.

8. Gramatikos dalykų prezentacijos būdai ir metodai (gramatinių posistemių sudarymas, algoritmų sukūrimas ir t. t.) - gali būti kitos tyrimo temos.

Receptyvusis gramatinis minimumas nagrinejjamas daugelyje lingvistikos ir metodikos darbų. Deja, aktyvusis gramatikos minimumas tiriamas kur kas menkiau. Daugelyje darbų aprašomi sintaksès modeliai, jų mokymosi metu atsirandantys sunkumai ir mokymosi tvarka. Toks neadekvatus aktyvaus gramatikos minimumo traktavimas, mūsų nuomone, atsiranda dèl dvejopo ir skirtingo požiūrio ị šnekamosios kalbos gramatikos mokymą: mokymas tik naudojant tipinius pavyzdžius, šablonus, struktūrų modelius; mokymas pasitelkiant taip pat paradigmatikos sąsajas. Pirmuoju atveju turètinas galvoje tam tikras sintaksės struktūrų nustatytos apimties bendravimo procese minimumas.

Laikantis antrojo požiūrio, numatytina pakankama bendravimui konkrečioje situacijoje gramatinių dalykų visuma. Tačiau ši visuma iš esmès skiriasi nuo pirmosios.

Mokslininkai metodininkai, pritariantys pirmajam požiūriui, praktiniam darbui davė daug daugiau gerų dalykų lyginant su antrojo požiūrio atstovais; užtektu paminèti M. Palmerio arba Č. Frizo darbus.

Mūsų katedrų daugiametė praktika parodè, kad nekalbinès aukštosios mokyklos vadovèliu autoriai turètų laikytis antrojo požiūrio. Nekalbinės aukštosios mokyklos programa kaip galutini mokymo tikslą numato išmokyti gebèti skaityti ir suprasti specialybès literatūrą ir kalbèti specialybès bei buities temomis. Todèl, jeigu laikytumès pirmojo požiūrio, privalètume turèti du skirtingus gramatikos kursus. Vieną - skaityti ir suprasti sudètingus mokslinius-techninius tekstus ir orientuotą i kalbos paradigmatiką, nes, norint teisingai atpažinti gramatines konstrukcijas, svarbūs pirmiausia formalūs požymiai. Antrasis gramatikos kursas būtų orientuotas ị kalbos sintagmatiką ir turi turèti nustatytą sintaksès modelių kiekį.

Žinoma, toks gramatikos sudvejinimas negalimas tik dèl to, kad bet kurio dalyko mokymasis vienu metu, prisilaikant dviejų susipriešinančių požiūrių, kalbos mokymo metodikos požiūriu neleistinas.

Apibendrindami mūsų samprotavimus, manome, kad, sudarant aktyvujji gramatikos minimumą, reikètų laikytis antrojo požiūrio. Pagrindinis atrankos kriterijus, mūsų nuomone, turètų būti gramatikos dalyko svarba generuojant ir realizuojant bendravimo situaciją ir tam tikras frazes. Iš to galime daryti svarbią išvadą: jeigu klaidos, vartojant gramatikos reiškini, pažeidžia komunikacijos proceso struktūrą ir jo prasmę, toks gramatikos dalykas, be abejonès, itrauktinas i aktyvuji gramatikos minimumą. Kitas svarbus momentas: jeigu sudarant konkretu pasakyma yra keletas sinonimiškų kalbos dalyku - mokymo tikslams parenkamas ne toks sudettingas ir sunkus.

Remdamiesi anksčiau minètais ir analizuotais teiginiais, siūlytume i aktyvuji vokiečių kalbos gramatikos minimumą įtraukti šiuos dalykus:

- Artikelio linksniavimą.

- Daiktavardžių daugiskaitos sudarymą.

- Būdvardžių laipsniavimą.

- Ivardžius (visus).

- Prielinksnius.

- Veiksmažodžių Indikativ laikų formų sudarymą (išskyrus Plusquamperfekt).

- Veiksmažodžių valdymą.

- Skaitvardžius.

- Sujungiamuosius jungtukus.

- Modalumo raiškos priemonès (Imperativ, modaliniai veiksmaž. ir kitos priemonės). 
- Neigimą reiškiančius žodžius ir priemones.

- Žodžių tvarką paprastame vientisiniame sakinyje.

Aktyvaus gramatikos minimumo dalykai mokymo procese turi būti išmoktini itin gerai, pasiekiant jų savaiminio vartojimo šnekamojoje kalboje lygi. Tam reikia daug produktyviąą kalbinę veiklą laiduojančių pratimų, kurie ugdo adekvačius mokèjimus ir igūdžius.

Reikalingų pratimų kiekis ir jų pobūdis įtvirtinant gramatikos dalykus - vienas iš pagrindinių aktyvaus ir pasyvaus gramatikos minimumo atskyrimo kriterijų. Studentai privalo turèti aiškią užsienio kalbos gramatikos mokymosi sampratą, tačiau vieni dalykai, atsižvelgiant i tam tikrus pratimus, išmoktini receptyviai, t. y. pasyviai, kiti produktyviai - atliekant skirtingus išmokimo pratimus.

Studentams pateikiant naujus gramatikos dalykus, išskirtini trys iš jų, kurie yra būtinas mokomojo darbo komponentas. Tai: 1) naujojo dalyko pateikimas; 2) supratimo kontrolè; 3) pirminiai pratimai naujam dalykui atpažinti arba jam pakartoti. Šnekamosios kalbos pirminiai pratimai yra diskursyvaus pobūdžio: žinant gramatikos dalyko reikšmes ir jo vartojimo galimybes, sudaromi elementarūs pasakymai.

Supažindinimas su naujuoju gramatikos dalyku pradètinas nuo gramatikos reiškinio aiškinimo, kad tolesnis darbas galètų remtis naujosios gretutines formos reikšmès išmanymu. Gramatinè medžiaga gali būti studentui pateikiama 1) kaip taisyklès; 2) kaip modelis; 3) derinant taisykles ir modelius; 4) glausta žodine forma. Taisyklès turètų būti trumpos, lakoniškos, aiškios, orientuojančios studentą i galutini tikslą, t. y. ì gramatinio dalyko vartojimą šnekamojoje kalboje arba jo atpažinimą ir susiejimą su reikšme skaitant arba klausantis kalbos.

\section{Išvados}

1. Mokant gramatikos, kalbinè recepcija ir reprodukcija yra du skirtingi dalykai. Pirmuoju atveju - tai gramatikos dalyko identifikavimas ir siejimas su teksto elementų reikšme. Antruoju atveju - išmoktų dalykų aktualizavimas, t. y. naudojimas naujoje situacijoje, turinio formaliai formai realizuoti.

2. Kalbos recepcijai ir produkcijai realizuoti reikalingi skirtingi gramatikos dalykai. Jie turètų būti atrinkti laikantis esamų atrankos kriterijų: receptyviajam minimumui - dalyko dažnumas ir jo vartojimas vienintelio ar kitokio pobūdžio tekstuose. Pagalbinis kriterijus būtų gramatikos dalyko sunkumo laipsnis, t. y. klaidų kiekis jị atpažįstant girdimajame arba rašytiniame tekste. Aktyvaus minimumo atrankos kriterijus yra gramatikos dalyko svarba generuojant ir realizuojant bendravimo situaciją ir tam tikras frazes.

3. Pasyviam ir aktyviam minimumui išmokti reikia specialių pratimų, kurie abiem atvejais gerokai skiriasi. Pirmuoju atveju vyrauja kalbos recepcija, antruoju - reprodukcija.

\section{Literatūra}

Benes, E. 1986. "Syntaktische Besonderheiten der deutschen wissenschaftlichen Sprache", in Deutsch als Fremdsprache, 3: 80-87.

Hoffmann, L. 1988. "Probleme der linguistischen Fundierung eines modernen fachbezogenen Fremdsprachenunterrichts", in Probleme der strukturellen Linguistik. Leipzig, 270.

Берман, И. 1978. Проблемы пассивной грамматики. Докторская диссертация. Москва, 468.

Щерба, П. 1974. Преподавание иностранных языков в средней школе. Москва: Просвещение, 112.

Остроухова, В. 1980. „Статистические данные для отбора грамматического минимума, необходимого при чтении литературы по специальности в неязыковом вузе“, в кн. Иностранные языки в высшей школе. Москва: Просвещение, 123. 


\title{
ACTIVE AND PASSIVE MINIMUM OF GRAMMAR IN TEACHING A FOREIGN LANGUAGE
}

\begin{abstract}
Aleksandras Velička
In this article the problem of active and passive minimum of grammar is analysed alongside with the questions relevant to this problem: the aspects of selection of grammar material, its presentation, teaching, consolidation and realization in communicational process. The author, while analysing students mistakes, states that the main criteria for selecting passive minimum of grammar must be the frequency of the subject and the possibilities of its usage in a definite text. The main factor for choosing active grammar minimum is communicative value of grammar. In the article it has been stated that different grammar exercises are needed for receptive and reproductive learning. The possibilities of grammar material presentation, consolidation and realization in a concrete situation are also touched on in the article.
\end{abstract}

Keywords: minimum of grammar, selection criteria, statistical record, types of linguistic activity, grammar patterns, linguistic statistics.

Iteikta 2006-01-16; priimta 2006-02-22 